\title{
A VÍZ ÉS A JÉG SZEREPE A CSILLAGOKTÓL A BOLYGÓTESTEKIG TARTÓ PLANETÁRIS FEJLŐDÉSI ESEMÉNYLÁNCBAN
}

\author{
Bérczi Szaniszló \\ ELTE Anyagfizika Tanszék, 1117 Budapest, Pázmány Péter sétány 1/A \\ e-mail: bercziszani@caesar.elte.hu \\ The role of water and ices in the planetary evolutionary sequence of events \\ from stars to planets
}

\begin{abstract}
We give an overview of the formation of the ice mineral belt in the Solar System and the planetary bodies that build up from them. In the second step, we outline the solar system phase of evolutionary history in the evolutionary system of matter.
\end{abstract}

Keywords: water, ice, mineral belts, planets, evolution, Solar System, Universe, structural hierarchy

\section{Összefoglalás}

A cikkben áttekintést adunk a) a Naprendszerben lévő jégövezet kialakulásáról az ásványövek között, majd b) a belölük fölépülő bolygótestekről. Ezt követően, második lépésként, elhelyezzük az így felvázolt fejlődéstörténet naprendszeri szakaszát az anyag fejlődéstörténeti rendszerében.

Kulcsszavak: víz, jég, ásványövek, bolygók, evolúció, Naprendszer, Világegyetem, szerkezeti hierarchia

\section{Bevezető gondolatok: szerkezeti hierarchia}

Az Univerzum leggyakoribb vegyülete a $\mathrm{H}_{2} \mathrm{O}$, ami számos anyagi rendszer formájában van jelen a planetáris környezetünkben. Ezek számbavételére igen alkalmas a szerkezeti hierarchia módszertana. Az anyag fejlődése során stabil struktúrákat épített fel. A stabil struktúrák egyfajta állandóságai az anyagnak, amelyek szerveződési szinteket képeznek. Egy magasabb egység (állandóság) mindig tartalmazza a fölépítésében részt vevő alacsonyabb hierarchia szint egységeit. A magasabb egység felöl tekintve ezt a rendszert, az alacsonyabb szintek egységei az elemek. A magasabb egység felöli bontással nyert elemek egymásbaágyazottsági sort képeznek (Bérczi, 1980). Az egymásba-ágyazottsági sor minden összetett rendszer felbontásának egyik terméke. E sorozathoz a szétszedem-összerakom alapelv alkalmazásával jutunk (Bérczi, 2017).

A szétszedem-összerakom alapelv nagy szerephez jut a modern gondolkodásban, de ritkán kap hangsúlyt. Pedig, a modern anyagvizsgálatok igénylik ezt a módszertant, különösen olyan összetett rendszerek elemzésénél, amelyek sok-sok lépcsőben bonthatók tovább. Esetünkben a „szétszedési müvelettel”, számos szerveződési lépcsőn át, a Naprendszert kapcsoljuk össze egyik molekuláris alrendszerével, a vízmolekulával. Tekintsük át ezt a fölbontási (és visszaépülési) sort! 


\section{Bolygótestek és kristályok}

Igen előnyös, hogy a Naprendszer és a molekuláris világ közötti tartományt egy átfogó tudományág régóta és egyidejüleg vizsgálja. Az anyagszerkezet és a földtest jelenségeit a 20. század közepéig a földtudományok fogták össze. A csillagászathoz tartozó jelenségkörbö1 az ürkutatás sokat kapcsolt a földtudományokhoz, és ezzel új szintézisbe rendezte i) a Földön, és ii) a „kozmikus óceán” naprendszerbeli szigetein szerzett ismereteinket. Ez a szintézis a geonómia és a planetológia keretei között a földi geológiában megalapozott ismereteinket planetáris hatáskörüvé terjesztette ki.

$\mathrm{Az}$ i) ásvány, ii) a bolygótest és iii) a Naprendszer élettelen környezetünk három alapstruktúrája. Párhuzamosan alakultak ki, de ezt a fejlődést még kevéssé részletesen ismerjük, így fejlődési szakaszokra kell bontanunk. A Naprendszer miniatür égitestjei, a meteoritok és az üstökösök jelzik, hogy az atomos és molekuláris anyag „,csomósodása” az ősi por- és gázködből csak a Napban zajlódott le közvetlenül, égitestet alkotva. A Napban az intenzív hőmozgás nem engedte kristályrácsba rendeződni a gázt fölépítő anyagokat. A Nap körüli hidegebb tartományokban azonban már molekulákká, majd kristályokká csapódott le a hülö gázanyag.

Ha a szerkezeti hierarchiára tekintünk (1.ábra), láthatjuk, hogy az ásványok tanulmányozása, megismerése a két nagyobb struktúra, a Naprendszer és a bolygótestek történetének a kulcsa. A fejlődés menetéről durva képet ad a végeredmény: a Naprendszerben két bolygótípus alkot egy belső és egy külső övet, ezek a Föld-típusúak és a Jupiter-típusúak. Ez volt az első differenciálódás a Naprendszerben. A krátersebek a bolygók felszínén ennek a záró epizódját jelzik. De a bolygókon is lezajlódott egy átrendeződési folyamat. (Ma még csak a Föld-típusúak ilyen eseményeit ismerjük.) A rétegsorok csak nagy vonalakban adtak képet erről. A felszínről hozott - vagy onnan ütközésekkel kiszakított - kőzetminták őrzik a bolygó finom léptékü eseménysorát. A „felszínről elhozás” ürkutatási eredmény, a „kiszakítás” kozmikus újraelosztási folyamat.

\section{A kondritos ásványi anyagok keletkezése az öves Naprendszer kialakulása során}

Az anyag fejlödéstörténetéről formálódó összképben döntő jelentőségü a meteoritok vizsgálata. A szilárd felszínü égitestekre simán leszállt ürszondák mérései előtt kizárólag a meteoritok tanulmányozásával gyüjtött kőzettani ismereteink voltak más égitestek anyagáról. A meteoritok anyagvizsgálata tárta föl, hogy a meteoritok ásványai, szöveti alkotóelemei, a Naprendszer születésének idejéből származnak (de vannak kis mennyiségben Naprendszer elötti időszakból származó alrendszerek, és találunk a már kialakult égitestekböl ütközéssel kiszakitott meteoritokat is, például marsi eredetüeket). A csillagászati modellekkel összhangban ma elfogadott az a nézet, hogy a csillaggá összehúzódó kozmikus por- és gázköd fölmelegedett, központi forró tartományai létrehozták a Napot, a körülötte keringő ködből pedig anyagcsomók váltak ki (kondenzálódtak). Ezek formálták a Naprendszer ásványait, amelyek ütközésekkel nagyobb égitestekké halmozódtak (akkréció). A meteoritok anyagvizsgálata során megkérdezhetjük, hogy e folyamatnak milyen „megfogható lépései” maradtak fenn. A meteoritok tehát fontos láncszemek akkor, amikor az anyag fejlődéstörténeti képét egyre részletesebben szeretnénk megismerni.

A Nap körüli por- és gázköd anyagát kétféle erő szervezte anyaghalmazokba, építette nagyobb testekké.

- Az egyik erő, mely elektromágneses és kvantumos hatások együttese, ásványszemcséket hozott létre. Apró szemcsékben kristályok váltak ki, amelyek az ütközések során összetapadtak, s egyre nagyobb anyaghalmazokká álltak össze. 
A másik erő, a gravitáció, fokozatosan jutott szervező szerephez a bolygók anyagának fölhalmozódása és megformálása során. A kilométeres nagyságú égitestek, a planetozimálok, ütközéseikkel egyre nagyobb méretü égitestekké tömörültek, amelyek egymás pályáit már egyre nagyobb mértékben befolyásolták (Bérczi, 1979).

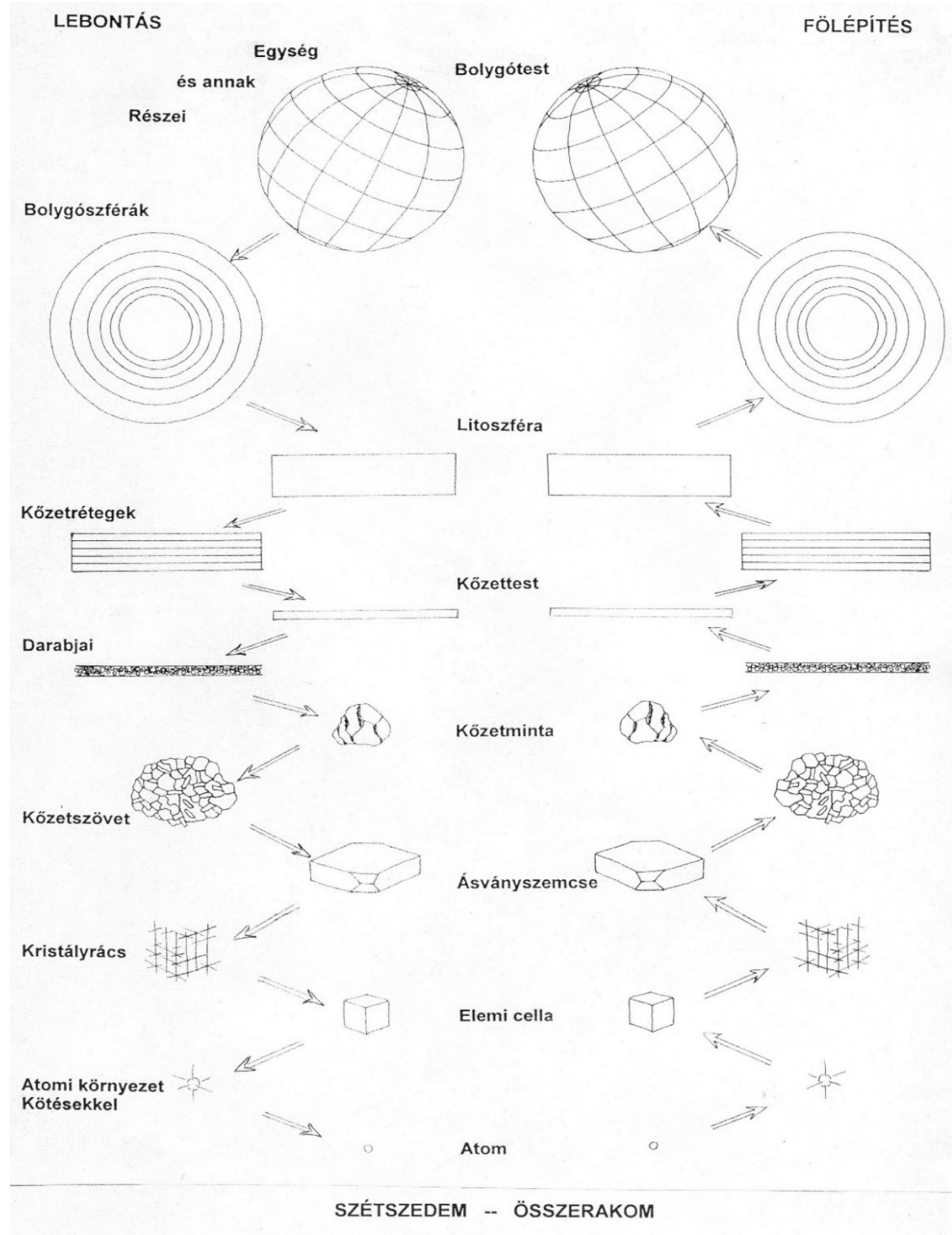

1. ábra: A Földtest szerkezeti hierarchiája a geoszféráktól bontva. Az ábra a szerkezeti hierarchia kőzettest és a molekuláris szint közötti szakaszát mutatja. A baloldali oszlop a szétszedés, a jobboldali oszlop az összerakás szempontjából nyilazza az irányokat a szerkezeti szintek között.

Figure 1: The structural hierarchy of the Earth decomposed from the geospheres. The figure shows the structures of the interval between the Earth's body and the atomic-molecular levels. The left column exhibits the sequence according to the decomposition. The right side column exhibits the building up sequence. 
A Naprendszer a Napot körülvevő anyagokból és égitestekből áll. Mindegyik égitest és anyaga is a korai Napot körülvevő por- és gázködből alakult ki. E por- és gázköd tömege mintegy századrésze a Nap tömegének, de a Naprendszer forgó mozgását ezek a Napon kívüli anyagok hordozzák keringő mozgásukban. A Nap körüli köd a Nap fölmelegedésével együtt fölforrósodott a belső, napközeli tartományokban, majd később lehült. A Naptól való távolsággal együtt változott a köd hőmérséklete, s ezzel a kristályos anyagok összetétele. A legfontosabb ásványok sorozatát táblázatunk mutatja be a Barshay \& Lewis (1975) féle modell szerint. A kondritos meteoritek fóásványai ebből az ásványsorból épülnek föl (1. táblázat).

\section{1. táblázat: Az ásványövek sorozata a Nap körül.}

Table 1: The minerals belts around the Sun.

\begin{tabular}{|l|l|l|}
\hline Hómérséklet [K] & Kémiai elemek, reakciók & Ásványok \\
\hline 1600 & $\mathrm{CaO}, \mathrm{Al}_{2} \mathrm{O}_{3}, \mathrm{Ritka}$-földfém-oxidok & Oxidok \\
\hline 1300 & $\mathrm{Fe}, \mathrm{Ni}$ fémötvözet & Fe-Ni fém \\
\hline 1200 & $\mathrm{MgO}+\mathrm{SiO}_{2} \rightarrow \mathrm{MgSiO}_{3}$ & Ensztatit \\
\hline 1000 & $\mathrm{Alkáli}-$ oxidok $+\mathrm{Al}_{2} \mathrm{O}_{3}+\mathrm{SiO}_{2}$ & Földpát \\
\hline $1200-490$ & $\mathrm{Fe}+\mathrm{O} \rightarrow \mathrm{FeO}, \mathrm{FeO}+\mathrm{MgSiO}_{3}$ & Olivin \\
\hline 680 & $\mathrm{H}_{2} \mathrm{~S}+\mathrm{Fe} \rightarrow \mathrm{FeS}$ & Troilit \\
\hline 550 & $\mathrm{Ca}$-ásványok $+\mathrm{H}_{2} \mathrm{O}$ & Tremolit \\
\hline 425 & ${\text { Olivine }+\mathrm{H}_{2} \mathrm{O}}_{\text {Szerpentin }}$ \\
\hline 175 & $\mathrm{H}_{2} \mathrm{O}$ jég kristályosodik & Vízjég \\
\hline 150 & gáz $\mathrm{NH}_{3}+$ jég $\mathrm{H}_{2} \mathrm{O}=\mathrm{NH}_{3} \cdot \mathrm{H}_{2} \mathrm{O}$ & Ammónia-hidrát \\
\hline 120 & gáz $\mathrm{CH}_{4}+$ jég $\mathrm{H}_{2} \mathrm{O}=\mathrm{CH}_{4} .7 \mathrm{H}_{2} \mathrm{O}$ & Metán-hidrát \\
\hline 65 & Metán, kristályos Argon & Metánjég, argonjég \\
\hline
\end{tabular}

A Naphoz közeli forró tartományokban kiváló ásványok sorozatát Larimer (1967) és Grossman (1972) határozta meg. Ezek jelentőségét az adja, hogy a kondritos meteoritek kis mennyiségben ennek a forró övnek az ásványait is tartalmazzák (2. táblázat).

2. táblázat: A nagy hőmérsékletủ ásványsorozat.

Table 2: The high temperature mineral belts.

\begin{tabular}{|l|l|l|}
\hline Hőmérséklet $[\mathbf{K}]$ & Kémiai elemek, reakciók & Ásványok \\
\hline 1785 & $\mathrm{Al}_{2} \mathrm{O}_{3}$ & Korund \\
\hline 1647 & $\mathrm{CaO} \cdot \mathrm{TiO}_{2}$ & Perovszkit \\
\hline 1625 & $2 \mathrm{MgO} \cdot \mathrm{Al}_{2} \mathrm{O}_{3} \cdot \mathrm{SiO}_{2}$ & Melilit (Gehlenit) \\
\hline 1513 & $\mathrm{MgO} \cdot \mathrm{Al}_{2} \mathrm{O}_{3}$ & Spinell \\
\hline 1471 & $\mathrm{Fe} \cdot \mathrm{Ni}$ & Vas-nikkel ötvözet \\
\hline 1450 & $\mathrm{CaO} \cdot \mathrm{MgO} \cdot 2 \mathrm{SiO}_{2}$ & Diopszid \\
\hline 1444 & $2 \mathrm{MgO} \cdot \mathrm{SiO}_{2}$ & Forszterit \\
\hline 1362 & $\mathrm{CaO} \cdot \mathrm{Al}_{2} \mathrm{O}_{3} \cdot 2 \mathrm{SiO}_{2}$ & Anortit \\
\hline 1349 & $\mathrm{MgO} \cdot \mathrm{SiO}_{2}$ & Ensztatit \\
\hline
\end{tabular}

Mindkét ásványsorozat tagjai közvetlenül meg is figyelhetők a meteoritokban. Barshay \& Lewis (1975) modellje - ahogy említettük már - a kondritokban, a Grossman-Larimersorozat pedig a CAI (kálcium-alumínium-oxid) zárványokban található meg. Ezekről szólunk 
most részletesebben.

\section{A kálcium-alumínium-oxid zárványok (CAI)}

A belső Naprendszer kondenzálódó ásványait az iparban tűzálló kerámiákként emlegetett anyagokként nevezhetjük meg (Ilyen például a korund, a perovszkit, a spinell). Ezek az ásványok kicsiny halmazokba gyültek össze és egymásra rétegződve kristályosodtak. Kondritos meteoritokba beépülten találjuk őket $(\mathrm{CAI}=\mathrm{Ca}$-Al-Inclusions $=\mathrm{Ca}$-Al-zárványok $)$. Egy CAI réteges fölépülését folyamatosan növekedő kristályos anyagcsíraként képzelhetjük el. Elöször a korund $\left(\mathrm{Al}_{2} \mathrm{O}_{3}\right)$, és a perovszkit $\left(\mathrm{CaTiO}_{3}\right)$, válik ki, majd sorra melilit $\left(\mathrm{Mg}_{2} \mathrm{Al}_{2} \mathrm{SiO}_{7}\right)$, spinell $\left(\mathrm{MgAl}_{2} \mathrm{O}_{4}\right)$, majd diopszid $\left(\mathrm{CaMgSi}_{2} \mathrm{O}_{6}\right)$, végül anortit $\left(\mathrm{CaAl}_{2} \mathrm{Si}_{2} \mathrm{O}_{8}\right)$ rétegek következnek. CAI ásványok (fehér zárványok) összetételét először Sztrókay Kálmán magyar kutató mérte meg a kabai meteoritban. Röntgendiffrakciós méréseiben Sztrókay a fehér zárványokat spinell összetételünek találta (Sztrókay et al., 1961).

\section{A kondrumok kialakulása}

A fő kőzetalkotó szilikátok adták a belső bolygók övében kiváló ásványok nagy részét. Ezek olvadékcseppeket hoztak létre, mert a korai Nap kitörései egyes tartományokban úgy fölforrósították a por- és gázködöt, hogy az addig már kialakult és összetapadt kristályok megolvadtak, majd lehültek. A tizedmilliméteres-milliméteres nagyságú gömböcskékre (a kondrumokra) fokozatosan tapadt rá a körülöttük található por is. A kondrumok és a maradék poranyag összetapadással és ütközésekkel egyre nagyobb égitestekbe halmozódott. A mai kondritos meteoritek azokból a kisebb méretü kondritos égitestekböl származnak, amelyek nem melegedtek föl a Naprendszer elmúlt négy és fél milliárd éve alatt.

A megolvadt cseppek kihültek, kikristályosodtak. E kondrumok, mint a Nap körüli porfelhő szemcséi, beépültek az apró szemcsés alapanyagú kondritos meteoritokba. A kondrumok többféle szövetüek lehetnek, ahogyan ezt a mikroszkópban a vékonycsiszolatokon megfigyelhetjük (2. ábra). A kőzettanban használt nevükön adjuk meg a hat fó típust. Lehetnek belső szöveti mintázatot nem, vagy alig mutató üveges vagy kriptokristályosak (1), sugarasak (angolul excentro-radiálisak) (2), lemezesek (angolul barred) (3), porfírosak (4), granulárisak vagy szemcsések (5) és poikilites piroxén kondrumok (6). E kondrumok gyorsabban, lassabban lehült szilikátolvadék cseppekből keletkeztek. Az olvadékok összetétele is fokozatosan változott helyröl helyre a Naprendszerben. Mind a hatféle kondrum előfordul a különféle kondrit-típusokban, de különböző arányban vannak bennük. A kondrittípusokat ásványtani és kémiai tulajdonságaik alapján osztályozták.

De a kondrumok megörizték a Nap körüli gázködben lezajlott eseményeket a környezetükben található anyagok ásványos és kémiai összetételében is. A kondrumok egy része, miután megszilárdult, még különféle változásokon esett át addig, amíg a kondritos kisbolygók anyagává vált. A kondrumok körül különféle peremeket találunk. Ezek részben még a Nap körüli por- és gázködben lezajlott események tanúi, más peremek viszont már a kis égitesten lezajlott (pl. vizes és/vagy mikrobiális) átalakulás termékei. Egyes kondrumoknak aprószemesés kristályok alkotta porpereme van, ami arra utal, hogy a kondrum, megszilárdulása után még hosszú ideig sodródott a Nap körüli por- és gázködben, míg hozzá nem tapadt egy halmozódó anyagcsoporthoz. Egyes kondrumokat éppolyan magmás szövetü perem vesz körül, mint maga a szilikátcsepp anyaga. Ezek úgy jöhettek létre, hogy a már megszilárdult kondrum felületére gyült port újabb napkitörés megolvasztotta. Egyes kondrumok a külső részeiken, vagy a peremükön tartalmazzák a fémes vas-nikkel cseppeket. Ez arra utal, hogy a kondrumok forogtak, ezért a nagyobb sürüségü összetevők fokozatosan a kondrum felületére sodródtak (Bérczi, 2018a, b). 

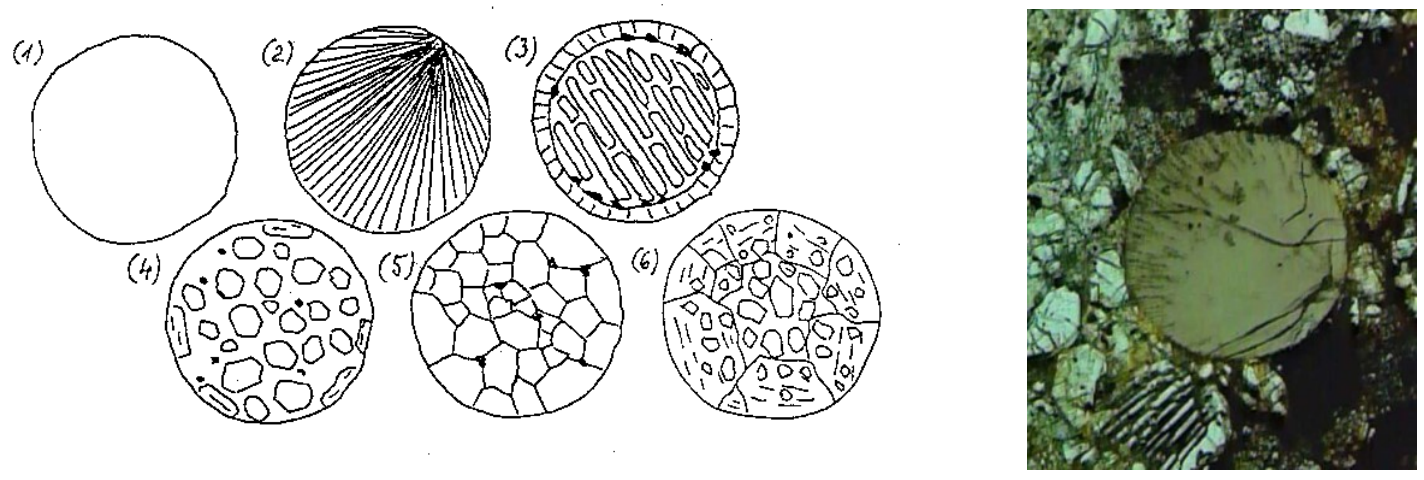

2. ábra: A kondrumok szövete többféle lehet, ahogyan ezt a mikroszkópban a vékony-csiszolatokon megfigyelhetjük (bal oldali rajz). Egy üveges kriptokristályos kondrum a kondritos szövetben.

Figure 2: The textures of the chondrules can be variable, as shown they appear in the microscope chondrule (left drawing). Image of a glassy cryptocrystalline chondrule is in the chondritic matrix.

A meteoritok anyaga a kisbolygókból származik, a $\mathrm{H}_{2} \mathrm{O}$-jég a külső holdakon gyakori. A kisbolygók reflexiós színképének a meteoritek színképével történt összehasonlításával már az 1970-es évekre átfogó kép alakult ki a csillagászatban arról, hogy a meteoritek forráshelye a kisbolygók öve. Ez az öv mintegy választóvonal a belső Naprendszer és a külső Naprendszer között. Az 1980-as évekre már a kisbolygó övön belül is zónákat tudtak elkülöníteni, amelyekre más és más uralkodó kisbolygó-színkép-típus volt a jellemző (Gradie \& Tedesco, 1982).

A kisbolygó-öv külső peremén a szenes kondritok a gyakoriak. $\mathrm{S}$ bár ma még nem rendelkezünk kőzettani módszerekkel elemezhető mérési anyaggal a külső Naprendszer jegeket is tartalmazó ősi anyag együtteseiről, ezeknek a színképében már előfordulnak a vízjégre jellemzö elnyelési vonalak. Ugyancsak a reflexiós színképek elemzésével mutatták ki azt is, hogy a külső Naprendszer egyik fó ásványi anyaga a $\mathrm{H}_{2} \mathrm{O}$-jég. Az óriásbolygók holdjai, a Szaturnusz gyürüjének anyaga és az üstökösök anyaga a legismertebb víz és jég azonosítások a külső Naprendszerben.

A Voyager, Galileo, Cassini és más ürszondák az óriásbolygók holdjait vizsgálták. Itt hatalmas vízmennyiség halmozódott fel (Weidinger \& Tasnádi, 2020). Ezeken található a kristályos $\mathrm{H}_{2} \mathrm{O}$ és a köpenyekben a folyadék állapotú $\mathrm{H}_{2} \mathrm{O}$ legnagyobb elérhető és megfigyelhető része. A Barshay \& Lewis (1975) féle modell értelmezhetővé teszi azt is, hogy miért a Jupiter távolságában jött létre a legnagyobb tömegü bolygótest. $\mathrm{A}_{2} \mathrm{O}$ az Univerzum legnagyobb mennyiségben jelen lévő vegyülete víz és jég fázisban, és ásványokba beépülve. Abban a zónában, ahol a szoláris köd vízjég anyaga kristályosodott, ott állt rendelkezésre a kozmikus elemgyakoriság szerinti legnagyobb kristályos anyagmennyiség ebböl a vegyületből. Érdemes azonban megvizsgálni a vízjég és a többi kristályos anyag jelenlétét a különböző csillaggenerációk elemproduktumainak fényében is!

\section{Anyagfejlődés a Naprendszerben}

A szoláris ködből kivált ásványok sorozata a 15 leggyakoribb elem figyelembevételével az 1. táblázatban található (Barshay \& Lewis, 1975; Bérczi, 1985, 1991). A kiválási sor két nagy csoportra bontható. 


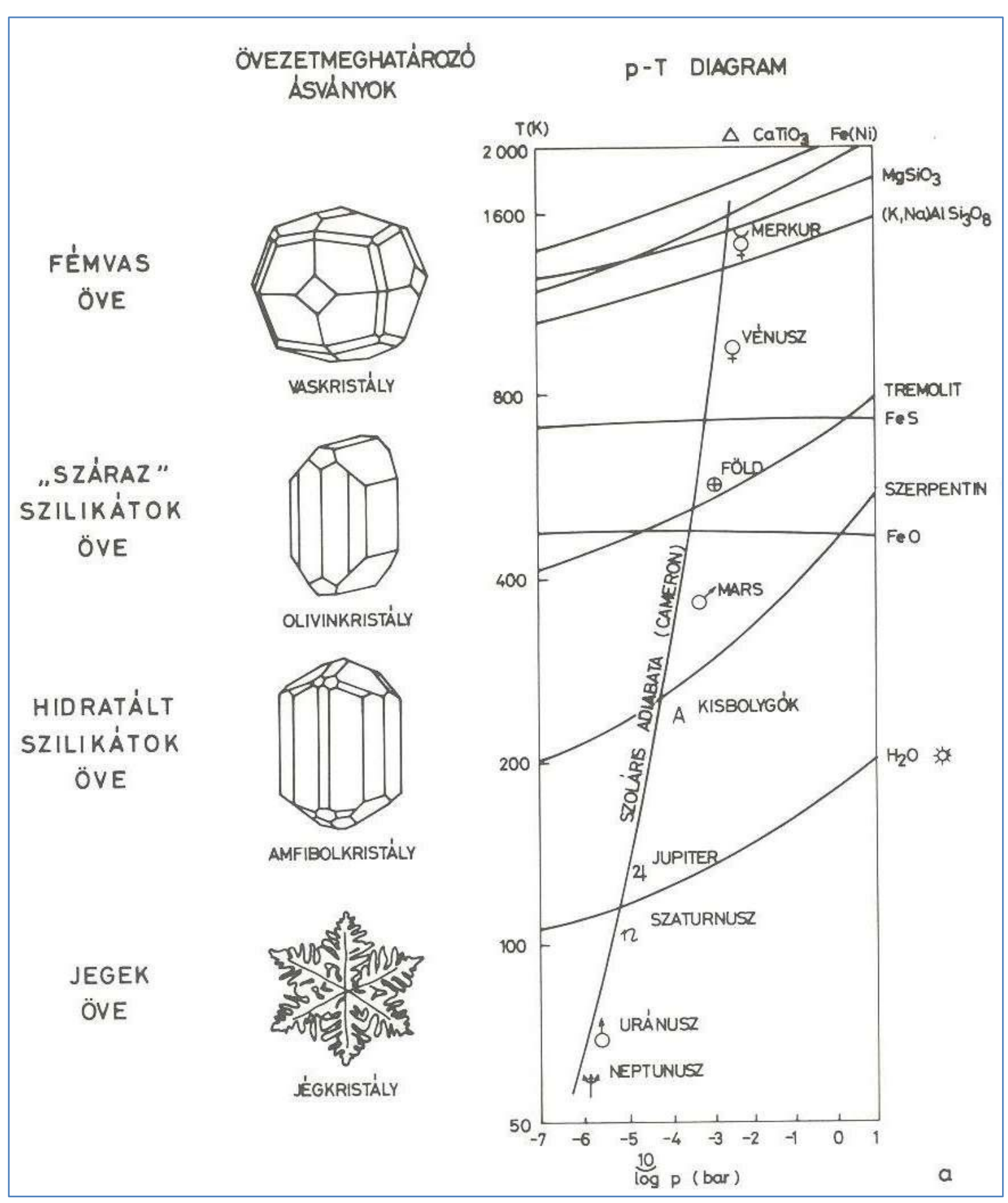

3. ábra: A Nap körüli zónák fö ásványi összetevői a Barshay \& Lewis (1975) modellje szerint (Bérczi, 1985 alapján).

Figure 3: The main mineral belts around the Sun according to the Barshay \& Lewis (1975) model (after Bérczi, 1985).

A nagy hőmérsékletü tartományban - a szoláris ködnek a Naphoz közelebbi övezetében a fémek oxidálódnak, majd szilikátokat képeznek (a vas ezektől eltérően a redukáló viszonyok miatt előbb fémes nikkel-vasként, később pedig a lassú oxidálódás és szilikátásványokba épülés mellett szulfidként van jelen). A Naptól távolabbi övezetekben a $\mathrm{H}_{2} \mathrm{O}$, az Univerzum leggyakoribb vegyülete is be tud épülni a szilikátokba, még távolabb pedig a kristályos anyag zömét jégkristályként adja, amelyet még metán- és ammónia-hidrát-jég kísér 
Bérczi Sz:

A víz és a jég szerepe a csillagoktól a bolygótestekig tartó planetáris fejlődési eseményláncban

(3. ábra). Az ásványoknak a szoláris köd hőmérséklet- és nyomás-tartományára megadott gáz-kristály fázishatárait a szoláris köd becsült adiabatájával elmetszve (3. ábra, jobboldal), becslést adtak az egyes Napkörüli zónák - tehát a zónákból összecsomósodott bolygók ásványi összetételére. Ezt a becslést az adiabata mentén folytatva a 4. ábrához jutottak.

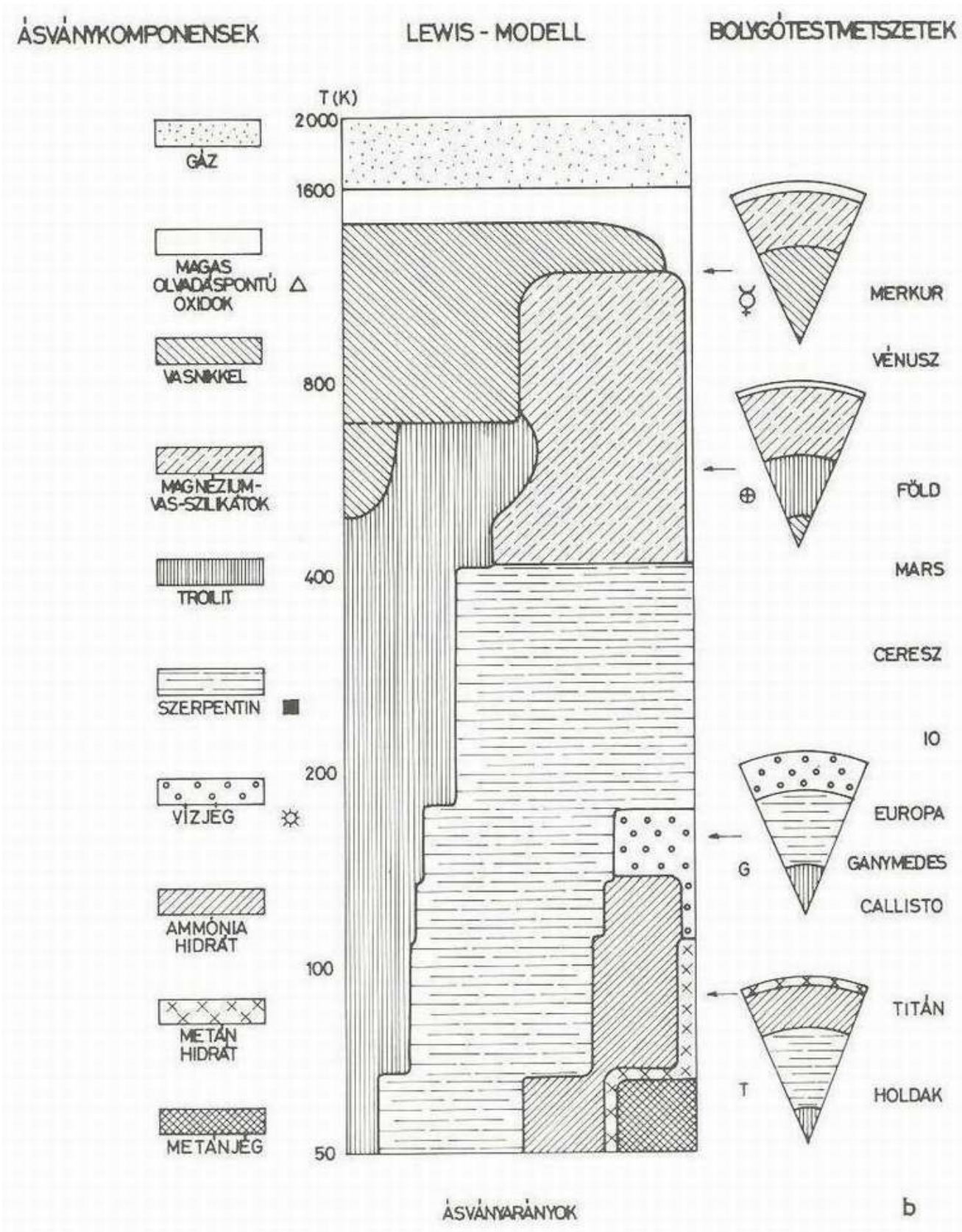

4. ábra: Nap körüli zónákból összecsomósodott bolygók ásványi összetétele Barshay \& Lewis (1975) modellje szerint.

Figure 4: Minerals and rock belts are inside the solar system planetary bodies. The minerals in the belts around the Sun had been precipitated according to the model of Barshay \& Lewis (1975).

A 4. ábra a bolygó középpontjától a felszínig egymásra következő rétegeket mutatja be, amelyek különböző hőmérsékleten (és az adott zónában) a szoláris köddel egyensúlyban lévő 
kristályos anyagból keletkeztek. Jól láthatók a belső bolygók és azok eltérő tulajdonságai. Tekintsük át ezeket!

- A Merkúr magas olvadáspontú fém-oxidokból, vas-nikkelből és korlátozott mennyiségben ensztatitból $\left(\mathrm{MgSiO}_{3}\right)$ épül föl.

- A Vénusz összetételében a Merkúrnál felsoroltak mellett a Nap elemgyakoriságának megfelelő teljes ensztatit és részben alkáli alumino-szilikátok is részt vesznek.

- Földünk már a $\mathrm{H}_{2} \mathrm{O}$-t is magukba építő szilikátok övezetének belső peremén akkumulálódott (állt össze).

$\mathrm{A}_{2} \mathrm{O}$ tartalmú szilikátok adták a földi víz jelentös részét. Ez azonban a Föld tömegéhez képest elenyészö (0,05\%), de a felszín közelébe koncentrálva mégis számottevő mennyiség. Megjegyezzük, hogy a Föld belsejében a vas háromféle kapcsolatban van jelen: fémes vas-nikkelként, az FeS-ben troilitként és az FeO-ban a köpeny olivinjében $(\mathrm{Mg}, \mathrm{Fe})_{2} \mathrm{SiO}_{4}$ és piroxénjében (illetve ezek nagynyomású ásványfázisaiban).

- A Marsban a vas már csak szulfid, illetve a szilikátokban oxidált formában van jelen.

$\mathrm{Az}$ ensztatit és az olivin mellett a $\mathrm{H}_{2} \mathrm{O}$ tartalmú szilikátok a Mars tömegének 0,3\%-át kitevő vízmennyiséget halmoztak a bolygóra. E belső zóna kristályait (oxidokat, szilikátokat, nikkel-vasat és szulfidokat) találjuk a meteoritokban uralkodó komponensekként. A kisbolygók látható fényben és közeli infravörösben felvett spektruma gyakran jó egyezést mutat a meteoritokéval, ami közös anyagi felépítésre, esetleg közös eredetre, forgácsolódásra utal.

A kivált kristályok a kondenzálódás második szakaszában rugalmatlan ütközésekkel halmazokba tömörültek. Ezt a folyamatot - amelyet gravitációs kristályosodásnak nevezhetünk a végső struktúrát, a bolygót egyesítő gravitációs erőről - szemléletesen a Nap körül keringő kristályos anyaghalmazok méret-spektrumán követhető nyomon. A négy spektrum egy-egy „pillanatfelvétel” a gravitációs kristályosodás négy korszakából (Bérczi, 1979, 1980, 1991):

- a szoláris ködből kivált kristályok uralkodóan mikrométeres nagyságúak (1);

- rugalmatlan ütközésekkel a piciny kristályok kilométeres testekké (planetozimálokká) állnak össze. Ezek már jelentősen módosithatják egymás pályáját (2).

- romboló ütközések is egyre nagyobb számban fordulnak elö, a méretspektrum darabolódási szakasza is megjelenik (3);

- a darabolódási szakaszban jelzett törmeléket a legnagyobb bolygótestek begyüjtik, és egy egyre ritkuló szinten álló darabolódási szakasz állandósul (4).

Az ütközéses forgácsolódást a kisbolygók és bizonyos meteorittípusok optikai (közeli infravörös) színképének hasonlósága bizonyítja. A darabolódási szakasz a kis égitestek méretspektrumából lenyomatként krátersürüségi diagramokkal az ősi bolygótestek felszínéről leolvasható (kráterstatisztika). A bolygótestek differenciálódása révén különböző bolygótörténeti korokban felszínre került rétegek (pl. Imbrium-emelet a Holdon) egymásra következő korszakokból örizték meg a Naprendszer kis égitesteinek méretspektrumát (Wilhelms \& McCauley, 1971).

\section{A vízjég helye az anyagfejlődéstörténeti kép Univerzumot átfogó horizontján}

Az égitestek felszínén található nagyléptékü anyagszerkezet megismerésének és e megismerés eseménytörténeti rétegződésének van egy ábrába süríthető megfogalmazása. Ez a geológiából 
származik. A geológia a kőzetrétegek tudományaként indult. Steno 350 éve ismerte föl és fogalmazta meg a települési törvényt (Steno, 1669). Ez kimondja, hogy a fluid (gáz, vagy folyadék) közegben ülepedéssel létrejövő kőzettestek felülről lefelé haladva egyre idősebbek, $\mathrm{s}$ mindig a legfelül települt réteg a legfiatalabb. Az 5. ábrán bemutatjuk azt az állapotsort, amit a település, a kőzettestek lerakódása hoz létre. A létrejövő rétegek sorozatát, rétegsorát egy piramis jellegü ,építménnyel” jelképezzük (5. ábra), amelyben legfölül áll a legfiatalabb réteg, s alatta rendre egyre idősebb rétegek következnek (Dudich, 1997).

E tudományág virágzására a legjobb példa, hogy a bolygótestek rétegeit is ezekkel a Steno nyomán kifejlesztett módszerekkel végzik ma is (Wilhelms \& McCauley, 1971; Wilhelms et al., 1987).

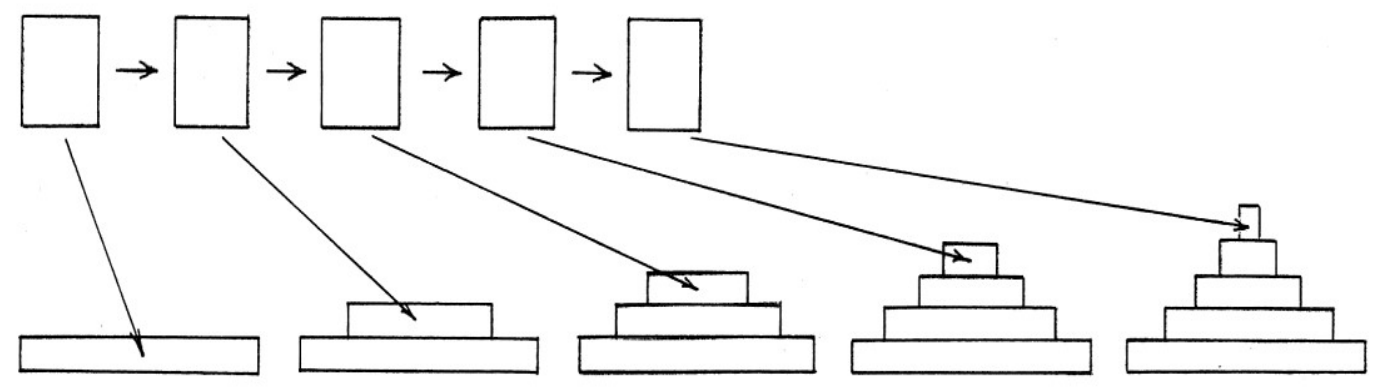

5. ábra: Steno első törvénye: a települési törvény. Az események leírása és a létrejött rétegtani állapotok leírása egy fölépülő rétegsor esetén. A rétegsor alján a korábbi, idősebb, fölfelé haladva pedig az egyre fiatalabb események rétegei következnek. Ez egy ideális rétegsor.

Figure 5: The first law of Steno is the law of settling (or sedimentation). This law asserts the description of the events during the sedimentation process which built up the stratified layer sequence.

The oldest rock layer can be found at the bottom of the corpus of the rock layers, and advancing upward we find the layers of gradually younger and younger stratum forming events. This is an idealized case.

Steno kimondott egy másik törvényt is: az a kőzetdarab, ami be van ágyazva egy másikba, idősebb a beágyazónál, vagy egykorú vele (Dudich, 1997). Az egymásba ágyazódási rétegsor sok mindenben hasonlatos az első Steno-törvényhez, de itt az egymásra következés mérettartományokat foghat át. Ilyen markánsan értelmezett rétegsor tehát az anyag - följebb szétszedéssel bemutatott - belső szerkezete is. Ezt a rétegsort eseménysorral, és szerkezeti hierarchiával is leképezhetjük. A szerkezeti hierarchia egy tartalmazási sorozat, amelyet „létraként” (1. ábra), és egymásba ágyazott körök sorozatával is ábrázolhatunk (6. ábra).

\section{Két szerkezeti hierarchia rendszer összekapcsolása: a geológia és a biológia (idővel a fizika) ,szövetsége"}

Eddig egyetlen hierarchia lépcsősort vizsgáltunk részletesebben, nevezhetjük ezt geo- vagy fiziko-lépcsősornak. A geológia az összetett jelenségek szétbontásával fejlődött és fejlődése során szoros kapcsolatot tartott a biológiával a kőzetekbe zárt ősi kövületek révén. A biológia a ma élő és megfigyelhető állat- és növényalakokat hozta kapcsolatba az ősi (megkövesedett) vázakkal. A fosszíliákban fennmaradt olyan alaksorozatokat és alakzat-együttesek sorozatát vizsgálta (pl. egykori élőlények), amelyek be vannak ágyazva a különböző korú kőzetekbe. A két tudományág a kutatások során fölismerte egymásrautaltságát. A geológia a beágyazott biológiai alak-együttesek alapján tudta a távoli rétegeket azonosítani (a földtani korreláció törvénye). A biológia viszont, a geológiában megalkotott rétegsorok segítségével, az egy 
időben élt állat- és növény-együttesekről kapott időbeli metszeteket tudta elemezni. Mindkét tudományág közremüködött tehát az evolúció törvényének fölismerésében (Darwin, 1909). A leglátványosabb evolúciós törvényszerüség - az élő alakzatok sorozatán - Haeckel nevéhez füződik, aki az embriók időben egymásra következő alakjaiban ismerte fel azt, hogy az egyedfejlődés - nagy lépésekben - megismétli a törzsfejlődést.

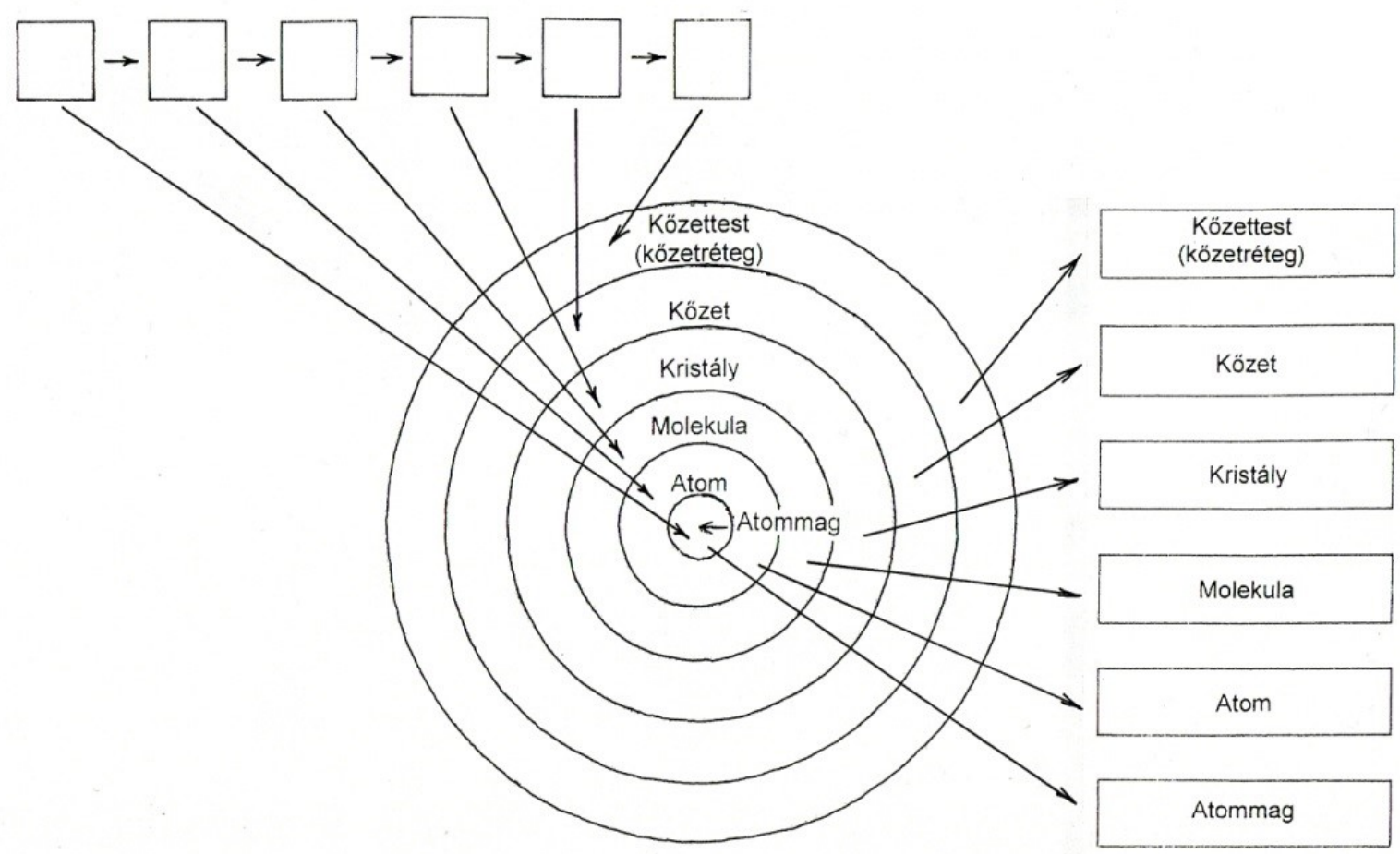

6. ábra: Steno-zárványok bezárási törvénye, kiterjesztve az anyag belső szerkezetéig, az atommagokig. A ,szétszedésnek”, a belső szerkezet föltárásának az eseményei az itt ábrázolt eseményekhez képest fordított sorrendben játszódtak le. Előbb ismertük meg a felsőbb hierarchia szinteket, majd idővel az egyre mélyebben fekvő szinteket (Bérczi, 1980). A mélyebb szintekhez különféle „szétszedési” módszerekkel juthatunk el.

Figure 6: The law of Steno on enclosing the inclusions can be extended till the innermost hierarchy level of nucleus of the atoms. The events of the decomposition (till the innermost structures) were carried out in a retrograde way: First we get acquainted with the structures on higher hierarchy levels, and gradually later we found the structures in the deep (Bérczi, 1980). We revealed the deeper layers by various decomposition (measuring) methods. 


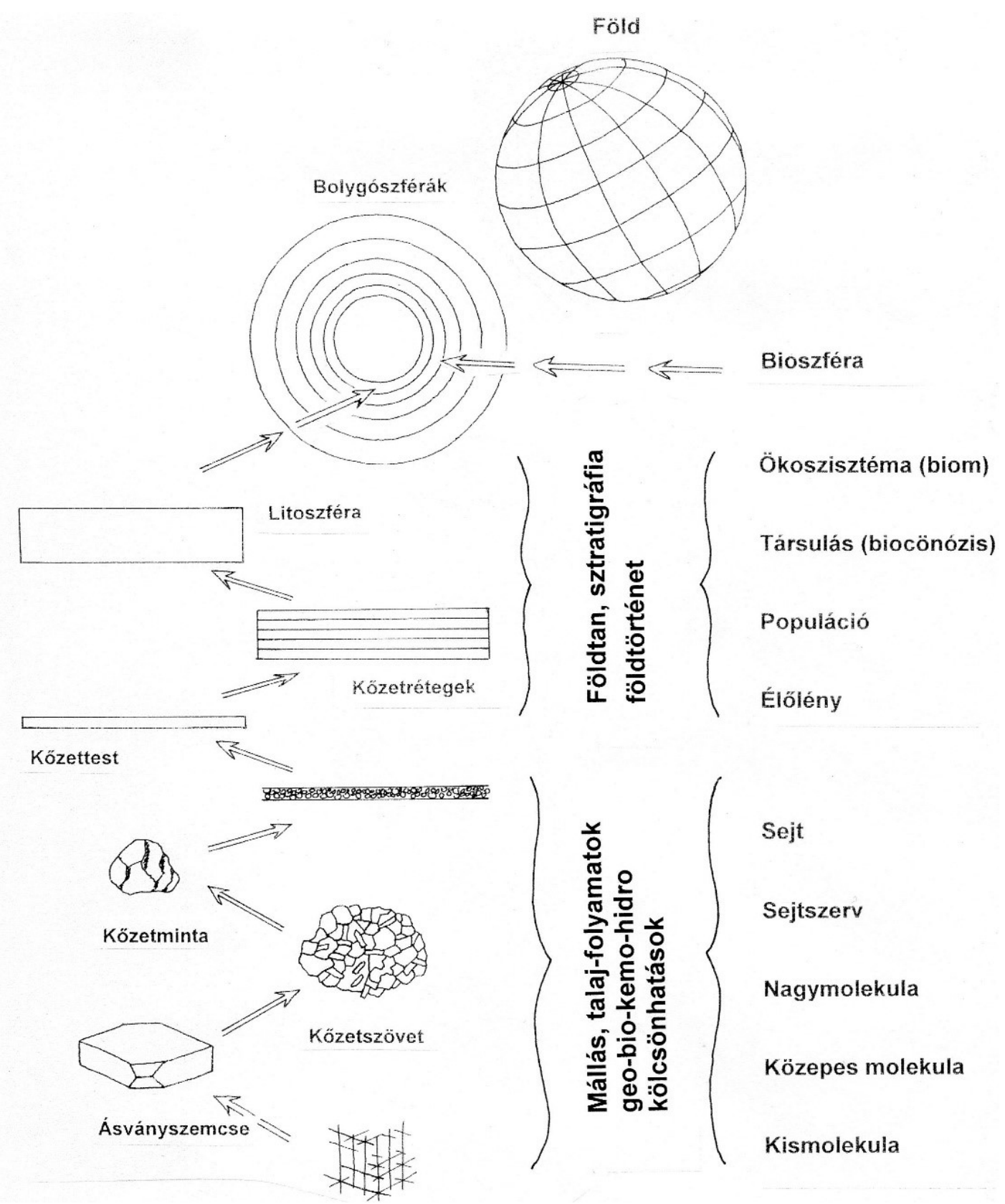

7. ábra: Két szerkezeti hierarchia sorozatot (fiziko-, geo- és bio-sorozatot) kapcsolt formában ábrázoló rendszer, ahol a középső sávban azokat a nagy földtudományi egységeket (geo-) emeltük ki, ahol a szintek csatolása lényeges szempontokat hoz a vizsgált alrendszerek elemzésénél (Bérczi, 2017).

Figure 7: Two disciplinary structural hierarchies are linked (physical and bio sequences). The middle belt (geo) between the two hierarchies focuses on larger geological topics where linking of the individual hierarchy levels contains essential questions in analyses of the subsystems.

A geológia mindkét egymásra képezést: a térszerkezeti hierarchiát és az időbeli egymásra következést is hasznosítja. A geológiai rendszer kiépülése idején - ahogy korábban már említettük - e szemléletmódot hasznosítani tudta egy másik tudományág, a biológia is, ami lényegében egyetlen hierarchia szintet, a testek megmaradó vázát tudta fölismerni és elemezni a közetrétegekbe beágyazott fossziliákon (7. ábra).

Ma már többféle tudományág hasznosítja a rétegsorok vizsgálatainál ezt a szoros kapcsolatot az egyes szerkezeti hierarchiaszintek jelenségei és folyamatai között (8. ábra). 

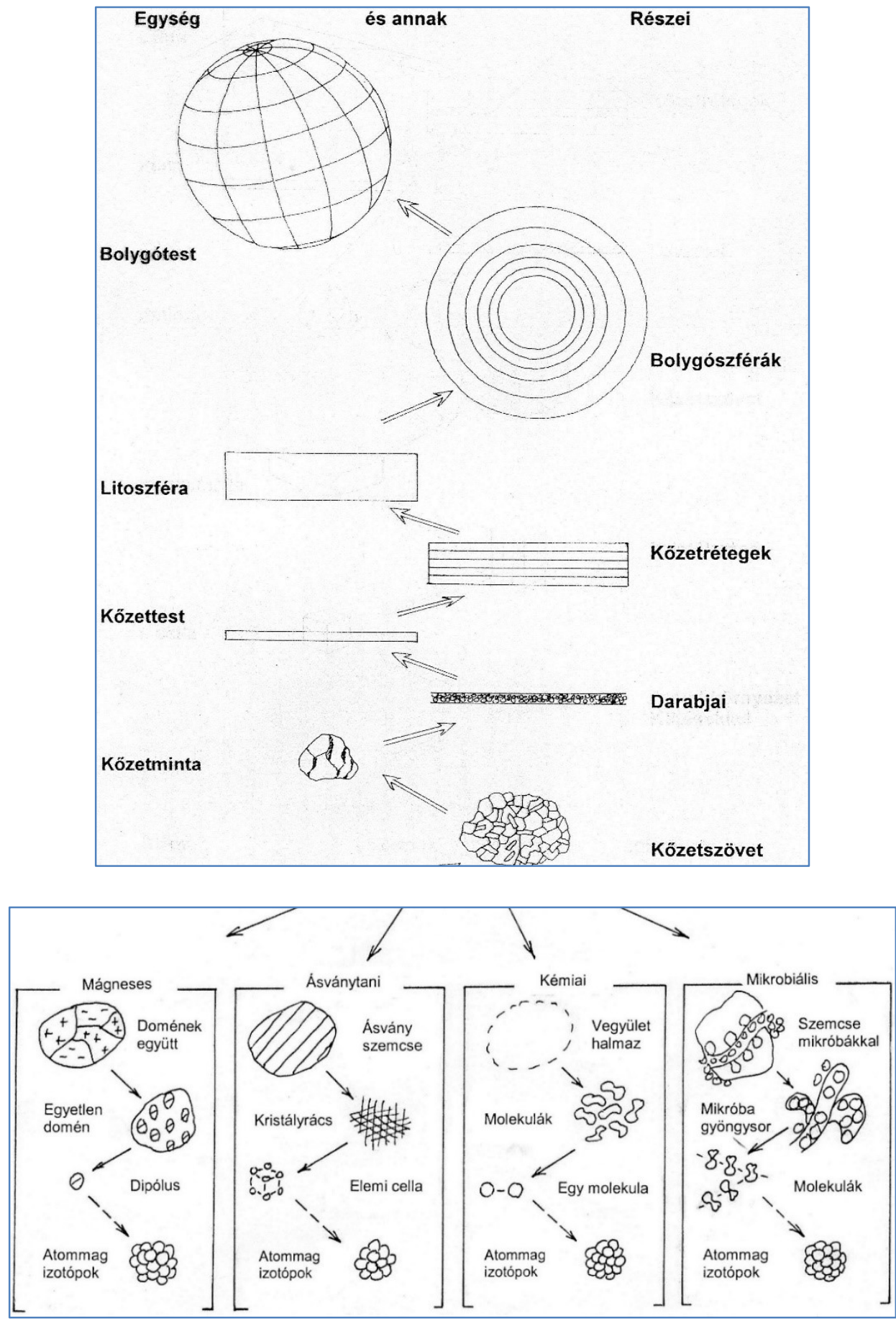

8. ábra: A szerkezeti hierarchia sor szétágaztatása a kőzetszöveti szinten, a fizikai, ásványkőzettani, kémiai és biológiai szintek („társszintek”) érzékeltetésével (Bérczi, 2018a, b). (A függőleges vonal mentén a tudományági hierarchiaszintek, vízszintes vonal mentén a különböző szakterületek azonos hierarchiaszintjei szerepelnek.)

Figure 8: The multiple furcation of the structural hierarchy sequences at textural level. The furcation results in a physical, a mineralogical, a chemical, and the biological co-levels (Bérczi, 2018a, b). (Along the vertical lines the hierarchy levels of various disciplines, along the horizontal lines the corresponding hierarchy levels of disciplines are given.) 


\section{A szerkezeti hierarchia fölhasználása a világegyetem szerkezetének kiépülését bemutató modelleknél}

A szerkezeti hierarchia és az eseménysorok nagyléptékü kapcsolata alapján rá tudunk mutatni több olyan lényeges anyag-fejlődéstörténeti kapcsolatrendszerre, amely az Univerzum jelentősebb korszakai során következett be (9. ábra).

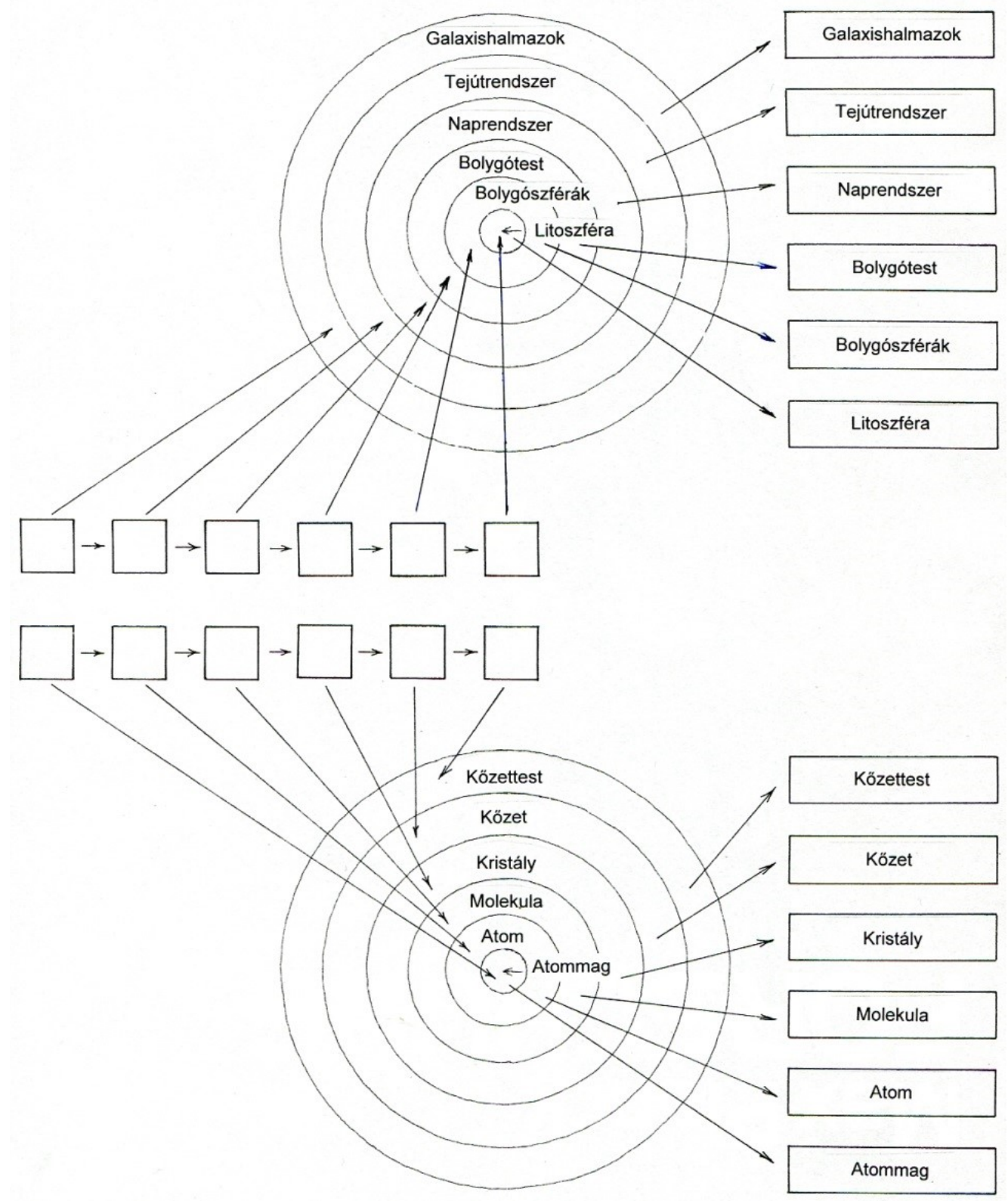

9. ábra: Két irányba kiépített szerkezeti hierarchia ábra sematikus képe. A felső hierarchiaszintek körbevesznek bennünket, az alsókat viszont mi (a testünkben például) tartalmazzuk. Ezzel a kettős rétegsorral a legkisebbtől a legnagyobbig átfoghatjuk az ismert szerkezeteket (Bérczi, 2017).

Figure 9: Cartoon of the structural hierarchy of material structures built on two directions: upward and downward. The structures of the upper hierarchy levels are around us, the structures of the lower hierarchy levels are contained inside our bodies. By this hierarchy sequence we may embrace the great number of structures of the material world. 
Az anyag-fejlödéstörténeti kapcsolatrendszer legfontosabb mozzanatait a 10. összefoglaló ábrán szemléltetjük. Az Univerzum néhány jelentősebb korai korszakára jellemző, hogy

- az Univerzum kezdetben üres, még nincsenek benne a mai világ belső struktúrái. A Forró Univerzum az elemi részek világával párhuzamosan fejlődött (1).

- Egy későbbi, természetesen folyamatosan ismétlődő, mégis a hierarchia-tábla szerint tagolható korszaka volt az, amikor a csillagok belsejében (felső szintek egyike) atommagok épültek ki (alsó, belső szintek egyike) (2).

- Egy fontos harmadik korszak volt az, amikor a csillag körül, a már jelen lévő nehezebb elemekből ásványövezetek alakultak ki: bolygótestek (felső szint) és ásványok (alsó szint) tartománya párhuzamos fejlődési szakaszban jött létre (Bérczi, 1979, 1980) (3).

- Marx György 80-as évekbeli elöadásain pedig egy olyan evolúciós folyamatszakaszt mutatott be, ahol az óceánokban (geoszféra, felsö szint) sejtfallal körülvett sejti szintü elemek (alsó szint) épültek ki és ezzel létrejött a Föld mai atmo-hidro-bioszférikus rendszere) (4). (A hátteret képező korábbi szinteket a 10. ábrán még nem tüntettük föl. A teljes hierarchia-kép a 11. ábrán jelenik meg.)

Ebből a négy példából is jól látható, hogy az Univerzum és az élet fejlődéstörténete során több alkalommal is csatolt szervezödési szintek együttes evolúciója zajlott le (Lukács et al., 1992). A korábban bemutatott 7. ábránk pedig arra utal, hogy a szerkezeti hierarchia ábrán mind a nagy evolúciós korszakok néhány csatoltan fejlődő szintje, mind ezek egymásutánisága, mind pedig - a jobb oldali 11b.ábrán - a belső és külső világ továbbfejlődés-története nagy vonalaiban jól ábrázolható. A szerkezeti hierarchia ábrázolásának egyik legfontosabb szervező képessége a szerkezetnek és a folyamatsornak ez az együttláttatása. (Erre jó példa az élettelen természetböl a $\mathrm{H}_{2} \mathrm{O}$-jég, ami az ásványok szintjén szerepel.)

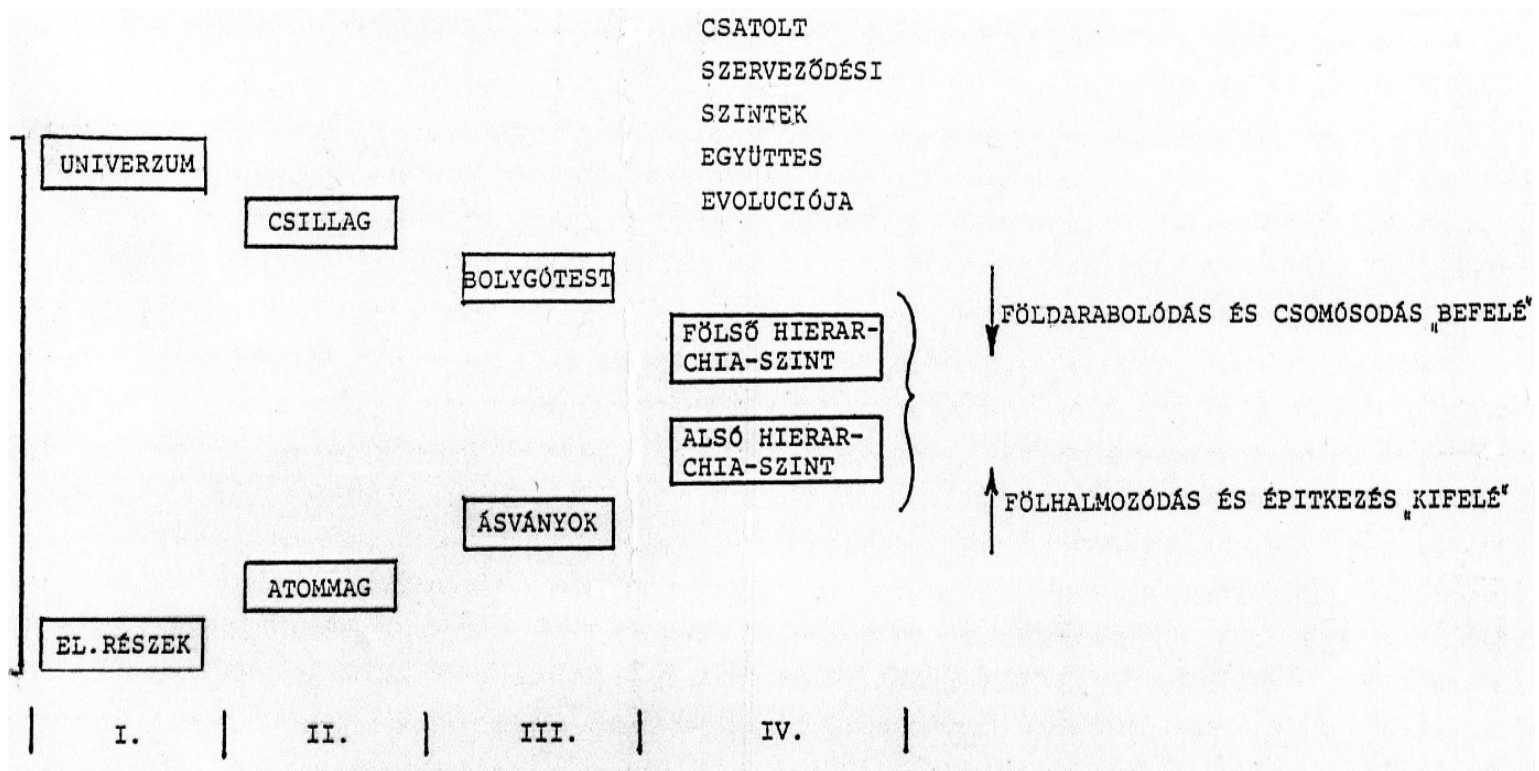

10. ábra: Az anyag fejlődéstörténetének korszakai, melyek leírhatók két, egymáshoz kapcsolódó hierarchiaszint párhuzamos fejlődésével.

Figure 10: The great periods of the evolution of matter. These periods can be described by the coevolution of two hierarchy levels: one from the outer (higher) level world and one from the lower (inner) level world. 
A forró univerzum korai szakaszában a részecskevilágban fölismert háttérsugárzásra és a galaxisok táguló világára utalunk az elsőként megnevezett (1-es) oszloppal a 10. ábrán. Ugyanígy párhuzamosan zajlott (és zajlik ma is) a csillagok belső folyamataiban az atommagok fölépülése (második oszlop, 2-es). Ebben már jelentős összetevő a vízjég. A 3. oszlop képzi mostani térképezésünk tárgyát: a bolygótestek kiépülését az ásványokból. Láthatjuk tehát, hogy a szerkezeti hierarchia alkalmazása az anyagfejlődéstörténeti modell összképbe rendezését segíti, ahhoz nyújt gondolkodási keretet. Az igen távoli jelenségek együttes látásában ez a szemléletmód nélkülözhetetlen.

\section{A vízjég előfordulása az Univerzum nagy fejlődési korszakaiban}

A 9. ábrán bemutatott szerkezeti hierarchia térkép segítségével megfogalmazhatjuk az anyag fejlödéstörténetének egy fontos vonását, ami a következő: az anyag fejlődéstörténetének több nagy korszaka leírható úgy, hogy a döntő események két, egymáshoz kapcsolódó hierarchiaszinten zajlanak (10. ábra). Ennek kibővített sematikus értelmezését adja a 11. ábra.

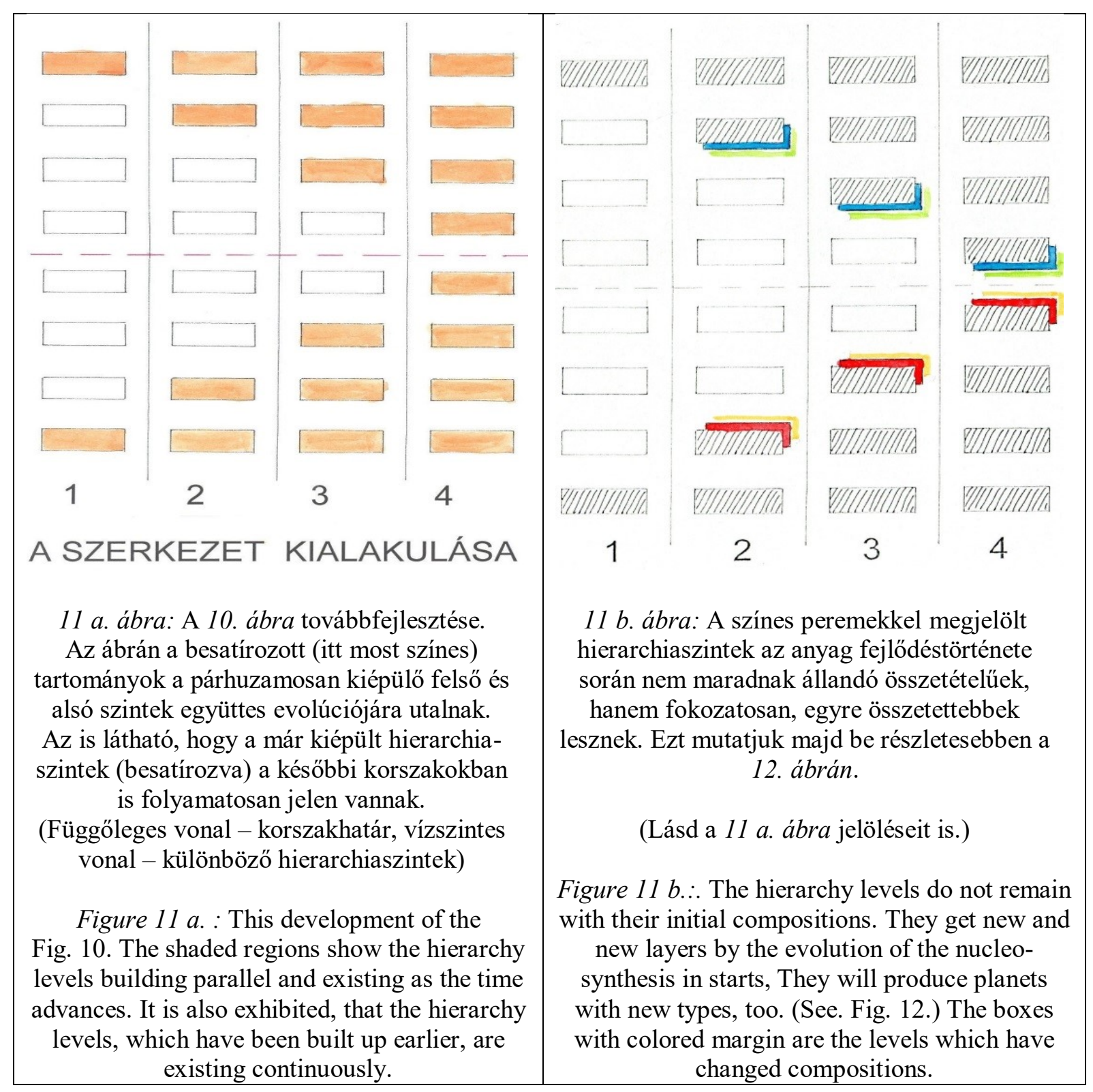


Több olyan szakaszt találunk az anyag fejlődéstörténetében, ahol két alapstruktúra párhuzamosan épült. Ilyen két struktúra szint az Univerzum Naprendszer előtti korszakában a táguló galaxis-világú Univerzum és a vele kölcsönhatásban hülő háttérsugárzás, a Forró Univerzum maradványa. Egy következő ilyen szerkezeti hierarchiaszint a páros csillag és az atommag szint. A csillagok és az atommagok hierarchiaszintje csatolásban fejlődött. Ennek lényeges következménye, hogy a korai csillagok elemkészlete még szegényes az egyes rákövetkező későbbi korszakok csillagaiétól, A vízjég szempontjából döntő szakasz az, amikor csillagok belsejében fölépülő atommagok elérik az oxigén atommagjának fölépülését eredményező szakaszt. Ezzel létrejön az Univerzum legfontosabb kémiai anyaga, a $\mathrm{H}_{2} \mathrm{O}$ (jég).

A csillagok az atommagok fokozatos továbbépítésével fokozatosan átalakítják az Univerzum kémiai anyagkészletét is. Ennek föltüntetéséhez előkészítésül kicsit átalakítottuk a 10. ábrát.

Azt, hogy a csillagokban felépülő újabb atommagok fokozatosan tovább építik a korai készletet a 11 a ábra mellett (itt csak a színezett épülő hierarchiaszintek láthatók) álló 11 b. ábrán színes peremek hozzáillesztésével érzékeltettük. (Ezt majd a 12. ábrán részletesebben is kifejtjük.) Mialatt az ásványok világa újabb ásványok csoportjaival gazdagodik, ezzel párhuzamosan a bolygótestek összetétele is gazdagodik és a csillagok körüli övesség is egyre tagoltabb lesz, ahogyan azt a Nap körüli ásvány öveknél már láthattuk (3. és 4. ábra).

Korai korszak - A vízjég már a legkorábbi szupernóvák anyagszétszórása után keletkezett csillagok körül is jelen lehetett, s ezeknek a csillagoknak ezért lehettek már Jupiter típusú bolygóik is. Ez egyúttal fölcsillantja az élet korai megjelenésének lehetőségét az Univerzumban (12. ábra). Az Univerzum korai időszakában már voltak olyan csillagok, amelyek a korai csillagfejlődés eredményeként a H, C, N, és O kémiai elemeket tartalmazták. Ezeknek a csillagoknak létrejöhettek olyan bolygói, amelyek a mi Jupiterünkhöz voltak hasonlók, és föleg jegekből álltak. A rendelkezésre álló kémiai készlet e korszak végén már lehetővé tette, hogy igen ősi állapotú nagymolekulák és sejtzsákok is létrejöhessenek (ez a mi feltételezésünk).

A Középső korszak (12. ábra) csillagainak kémiai elemkészlete már tartalmazhatott szilikátok fölépítéséhez alkalmas kémiai elemeket. Ennek rövid magyarázata az, hogy a nukleoszintézis a korábbi atommagok összeépülésével elő tudja állítani a harmadik periódus fémeit (a 12 ábrán a Na-t, az Mg-t, az Al-t és a Si-t jelöltük be ezek közül) a csillagok belsejében. E fémek alapján ebben a szakaszban már kőzetbolygókkal is számolhatunk a jegek mellett. A fémek az oxigénnel és a szilíciummal számos kőzetalkotó ásványt tudnak képezni. Ezek a Barshay \& Lewis (1975) modell szerinti belső, magasabb hőmérsékletü ásványi övezetet hozzák létre a középső korban kialakuló csillagok körül. A fémek közremüködésével, beépülésével az életnek is egy magasabb szerveződésű szintje képzelhető el.

A Jelenlegi korszak (12. ábra) csillag körüli felhőjében már a magasabb rendszámú elemek is böségesen jelen vannak. Ennek oka az, hogy a szupernova robbanások idején a nukleoszintézis eljut a vasig és egy kevés magasabb rendszámú elem is keletkezik. A Napunkhoz hasonló korú csillagok környezetében, a Barshay \& Lewis (1975) modell szerinti legbelső, magasabb hőmérsékletü ásványi övezetben létrejönnek már vasban gazdag ásványok is. Ezek összeállásával létrejöhetnek vas-szilikát bolygótestek. A vasban gazdag bolygótestek övezetét kezdte el már kiépíteni a Naprendszer is a Merkúr formájában. A Jelenlegi korszak evolúciós fejlődési foka is annak eredménye, hogy az élet összetettebb sejtvilága spóraként már rendelkezésre állhatott a Középső bolygókeletkezési szakaszban (Polgári et al., 2018, 2019; Gyollai et al., 2019). 
Bérczi Sz:

A víz és a jég szerepe a csillagoktól a bolygótestekig tartó planetáris fejlődési eseményláncban

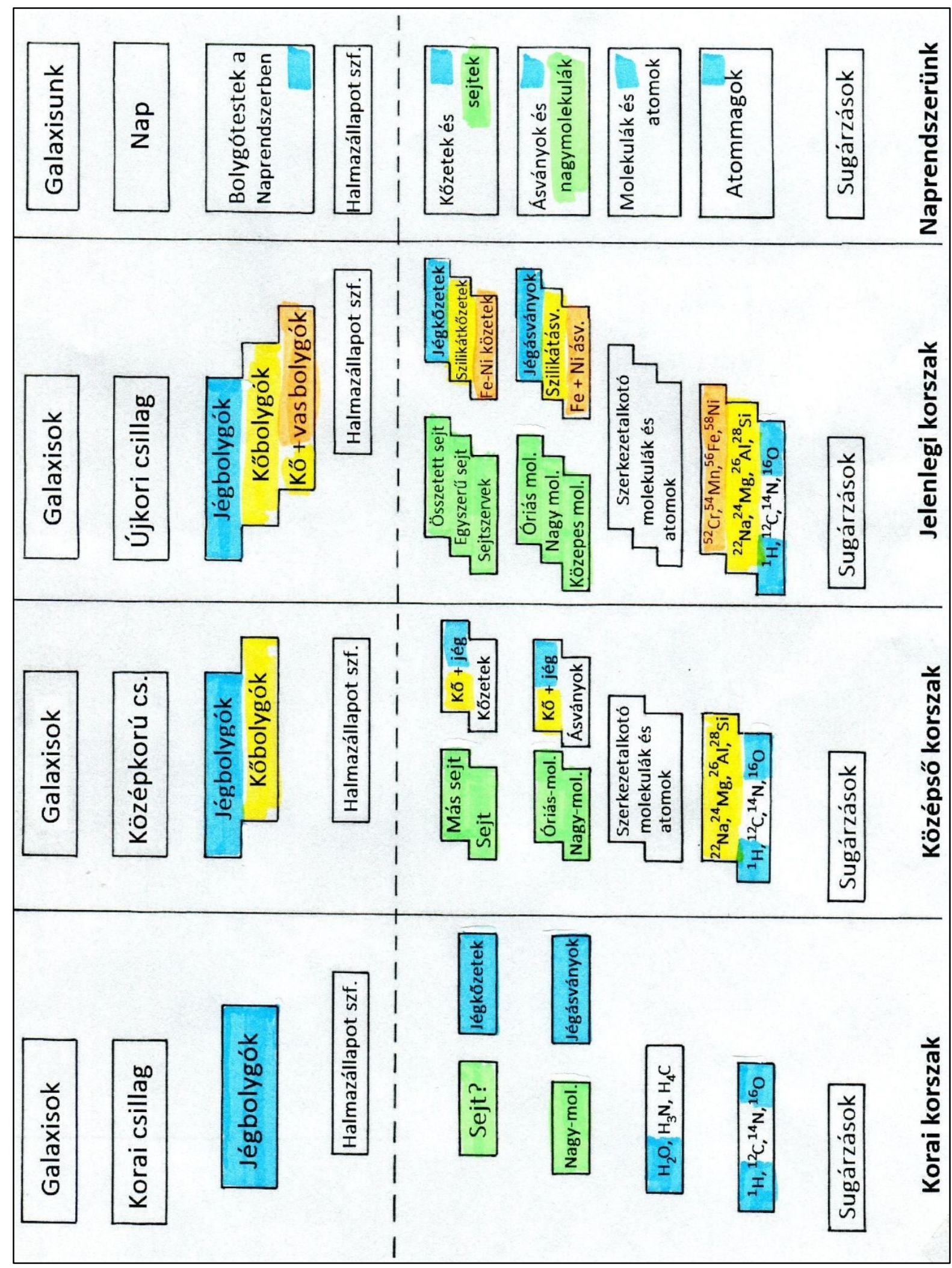

12. ábra: Összefoglaló és áttekintő ábra a jegek szerepéről az Univerzum fejlődéstörténetében. (Részletes ábraaláírás és magyarázat külön oldalon.)

12. figure: Summary of the role of water and ices in the evolution of the Solar system and the Universe. (More detail description on the separate page). 


\section{Részletes ábra magyarázat (lásd az elöző oldalt)}

12. ábra: Összefoglaló és áttekintő ábra a jegek szerepéről az Univerzum fejlődéstörténetében. Az ábra értelmezéséhez forgassuk el jobbra az egész oldalt! Ekkor a jobb szélső oszlop a Naprendszer jelenlegi szerkezeti hierarchia ábráját mutatja. Az ettől balra eső három oszlop az Univerzum három korábbi - Naprendszer előtti - korszakát mutatja szerkezeti hierarchiájában. Ez a három korszak a Korai korszak, a Középső korszak és a Jelenlegi korszak elnevezést viseli.

A Korai korszak csillagaiban már lehetett oxigén, ezért ezek szupernova robbanása szétszórta a $\mathrm{C}, \mathrm{N}, \mathrm{O}$, atommagokat az Univerzumban. Ezek egy része kristályos formában összeállhatott már Jupiter-típusú bolygóvá. Az csak egy sejtés, hogy korai sejtszerű formák már ekkor is létezhettek. A Középső korszakban már fölépült fém atommagokkal is számolhatunk. Ebben a korban már létrejöhettek kőbolygók is. Az élet korai szakasza is kiépülhetett a második nagy korszakban, egyszerü sejtes tartományokig. Ezeket szórták szét a Középső korszak csillagai. A Jelenlegi korszakhoz sorolt csillagok rendszerei már gazdag hierarchia mintázatot mutatnak. Az atommagok szintjén a nehezebb fémek (vas, mangán stb.) is jelen vannak. Belölük újabb ásványcsaládok épülhetnek föl (Hazen, 2010, 2013). A nehezebb vasásványok szinte már új övet rajzolnak meg a bolygókörüli térségben. (A Merkúrt már ide sorolhatjuk.) A sejtes élet nyomai már előfordulnak a meteoritokban (Polgári et al. 2019; Gyollai et al. 2019).

12. figure: Summary of the role of water and ices in the evolution of the Solar system and the Universe. (Please, turn the page to the right.) The right hand side column exhibits the hierarchy levels of the recent Solar System. The 3 columns of the figure show 3 different periods in the evolution of matter.

In the Earlier Period the early Universe has low level of new nuclei. In the Middle Period the stars produced some metal nuclei and these results in rocky planets in the higher hierarchy level. In the Recent Period the stars contain even Fe and other heavy metals. That is why the solar system contains the third mineral belt of Iron, and an almost metallic planet Mercury. The 3 periods clearly exhibits both the evolution of individual hierarchy levels (shown in Fig. 11 b. by colors) and the collective, larger scale evolution of the planets and planetary system. The 3 columns (counted from left in the table) are designated as Earlier Period (Korai korszak), Middle period (Középső korszak) and Recent period (Jelenlegi korszak).

\section{Összefoglalás}

Dolgozatunkban azt vizsgáltuk, hogy a $\mathrm{H}_{2} \mathrm{O}$ és jege milyen szerepet játszott az Univerzum fejlődéstörténetében. E szerep legegyszerübben az anyagszerkezeti hierarchia fejlődésén keresztül mutatható be. A szerkezeti hierarchia vázolása után a Naprendszer ásványainak és bolygóinak a keletkezési modelljével érzékeltettük, hogy a $\mathrm{H}_{2} \mathrm{O}$-jég övezet meghatározó jelentőségü a Naprendszerben.

Dolgozatunk második részében a Naprendszer fejlődéstörténeti modelljét „,beágyaztuk” az Univerzum fejlődéstörténeti modelljébe. Az egyesített modellt bemutató 12. ábrán a jobb szélső oszlopban a mai eredményt, a Naprendszer jelenlegi szerkezeti hierarchia ábráját mutattuk be. Az Univerzum szerkezetének eseménytörténeti fokozatait a mai Naprendszertől balra eső három oszlopban foglaltuk össze. A Korai korszakban, (bal oldali oszlop a 12 ábrán) amely az Univerzum korai szerkezeti hierarchiáját mutatja, már voltak olyan csillagok, amelyek a korai csillagfejlődés eredményeként a $\mathrm{H}, \mathrm{C}, \mathrm{N}$, és $\mathrm{O}$ kémiai elemeket nagyobb mennyiségben tartalmazták. Az ilyen csillagoknak már létrejöhettek olyan bolygói, amelyek hasonlatosak voltak a mi Jupiterünkhöz, tehát föleg gázokból és jegekből állnak. Feltételezhető, hogy a rendelkezésre álló kémiai készlet e korszak végén már lehetővé tette, hogy igen ősi állapotú nagymolekulák és sejtzsákok is létrejöhessenek.

A Középső korszak csillagainak kémiai elemkészlete már a szilikátok fölépítéséhez alkalmas kémiai elemeket is tartalmazhatott, mert fokozatosan tovább épült a csillagokban a periódusos rendszer atommagjainak sorozata. E csillagok körül már kőzetbolygókkal is 
számolhatunk a jegek mellett. A H, C, N, és $\mathrm{O}$ kémiai elemekből az élet legkisebb egységeinek a szerveződése is tovább folyhatott. Ezért a Középső korszak idején már számolhatunk egyszerü sejtek kialakulásával (és szétszóródásával).

A harmadik, a Jelenlegi korszakot bemutató oszlopban, a csillagok körüli felhőben már a magasabb rendszámú elemek is bőségesen jelen vannak. Ezért a jégbolygók mellett vasszilikát bolygótestek is létezhetnek (talán a Merkúr már ilyen). Ugyanakkor az élet összetettebb sejtvilága is már spóraként rendelkezésre állhatott a Középső bolygókeletkezési szakaszból.

Dolgozatunk és az egész Univerzum anyagfejlődéstörténetére kiterjedő áttekintésünk legföbb tanulsága az, hogy a víz kialakulásával párhuzamosan az élet is, már több korai bolygókeletkezési szakaszban kialakulhatott. Az élet müködéséhez a víz és a $\mathrm{H}_{2} \mathrm{O}$-jég már a nagyon korai időszaktól kezdve rendelkezésre állt az Univerzumban.

Köszönetnyilvánítás: A Szerző köszönetet mond Weidinger Tamásnak a 12. ábra készre szerkesztéséért, és azért, hogy bírálatával hozzájárult a cikk jobbá tételéhez.

\section{Hivatkozások}

Barshay, S.S., Lewis, J.S., 1975: Chemistry of solar material. In: The Dusty Universe. (A7615076 04-90) (eds. Field, G. B. \& Cameron, A. G. W.) Neale Watson Academic Publication, New York, 33-46. Bibliographic Code: 1975duun.book...33B

Bérczi, Sz., 1979: „Kettőskristályosodás” a Naprendszerben. Fizikai Szemle, 29(11): 412-419. http://fizikaiszemle.hu/archivum/fsz7911/tart7911.html

Bérczi, Sz., 1980: Cyclicity in the Evolution of Matter and its Application to the Evolution of the Solar System. Acta Geologica Academiae Scientiarum Hungaricae, 23: 1-4. 163-171. ISSN: 0001-5695

Bérczi, Sz., 1985: Anyagtechnológia I. Egyetemi jegyzet. Tankönyvkiadó, Budapest (J3-1333)

Bérczi, Sz., 1991: Kristályoktól bolygótestekig. Akadémiai Kiadó, Budapest, 193p. ISBN: 963-05-5842-4

Bérczi, Sz., 2017: Anyagszerveződési szintek a planetáris pedoszférák áttekintéséhez. (In: A talajtakaró geonómiája, A pedoszféra mint a Föld sajátos fázishatára. Az MTA X. Földtudományok Osztálya, Geokémiai, Ásvány-és Kőzettani Tudományos Bizottság Geonómiai és Planetológiai Albizottságának konferenciája, 2013. szeptember 26. és 27., Szerk.: Kubovics I., Póka T, \& Weidinger T.), Egyetemi Meteorológiai Füzetek, 28: 184-191. ISSN 0865-7920, ISBN 978-963-284-918-8(online), http://nimbus.elte.hu/oktatas/metfuzet/EMF028/EMF28.pdf

Bérczi, Sz., 2017: A szerkezeti hierarchia és a fölépítés-lebontás (szétszedem-összerakom) elv. Fizikai Szemle, 67(1): 32-36. https://epa.oszk.hu/00300/00342/00313/pdf/EPA00342 fizikai_szemle 2017 01 3236.pdf

Bérczi, Sz., 2018a: A kondritos meteoritek fejlödéstörténete a szülö égitesten. (The evolution of the chondritic meteorites on their parent body.) In: Átfogó kutatások a kabai meteoriton (Comprehensive Research on Kaba Meteorite). Szerk.: Nagy M., Rózsa P., McIntosh R. W., Acta Geoscientia Debrecina, Special Issue 1: 31-53. Debrecen University Press. ISSN 1788-44-97, ISBN 978-963-318-053-2

Bérczi, Sz., 2018b: Átfogó kutatások a kabai meteoriton: a konferencián elhangzott előadások csoportosítása a szülő égitest „,szétszedésének” szerkezeti hierarchiaszintjei szerint. (Comprehensive Research on Kaba Meteorite: Grouping lectures at the conference according to the structural hierarchy levels of the Kaba Parent Body). In: Átfogó kutatások 
a kabai meteoriton (Comprehensive Research on Kaba Meteorite). Szerk.: Nagy M., Rózsa P., McIntosh R. W. Acta Geoscientia Debrecina, Special Issue 1: 261-266. Debrecen University Press. ISSN 1788-44-97 ISBN 978-963-318-053-2

Darwin, K., 1909: Harcz a természetben. I. II. A Magyar Kereskedelmi Közlöny Hírlap és Könyvkiadó Vállalat, Budapest.

Dudich, E., 1997: Rövid Stenográfia. Földtani Közlöny, 127: 211-221. https://www.epa.hu/01600/01635/00284/pdf/EPA01635 foldtani kozlony_1997_127_12_211-221.pdf

Gradie, J., Tedesco, E., 1982: Compositional Structure of the Asteroid Belt. Science, 216 (4553): 1405-1407. https://doi.org/10.1126/science.216.4553.1405

Grossman, L., 1972: Condensation in the primitive Solar Nebula. Geochimica et Cosmochimica Acta, 36(5): 597-620. https://doi.org/10.1016/0016-7037(72)90078-6

Gyollai, I., Polgári, M., Bérczi, Sz., Gucsik, A., Pál-Molnár, E., 2019: Mineralized biosignatures in ALH-77005 Shergottite Clues to Martian Life? Open Astronomy (de Gruyter), 28(1): 32-39. https://doi.org/10.1515/astro-2019-0002

Hazen, R.M., 2010: The evolution of minerals. Scientific American, 302(3): 58-65. https://www.scientificamerican.com/article/evolution-of-minerals/ https://doi.org/10.1038/scientificamerican0310-58

Hazen, R.M., 2013: Paleomineralogy of the Hadean Eon. American Journal of Science, 313(9): 807-843. https://doi.org/10.2475/09.2013.01

Larimer, J.W., 1967: Chemical fractionation in meteorites. I. Condensation of the elements. Geochimica et Cosmochimica Acta, 31(8): 1215-1238. https://doi.org/10.1016/S00167037(67)80013-9

Lukács, B., Bérczi, Sz., Lábos, E., Molnár, I., 1992: Mutual Dynamics of Organizational Levels in Evolution. (Csatolt szerveződési szintek együttes evolúciója) MTA-KFKI-199232/C, Budapest 137p.

Polgári, M, Gyollai, I., Bérczi, Sz., 2018: Microbially mediated transformation inside the Kaba meteorite? (Mikrobiális átalakulás a Kaba meteorit belsejében?) In: Átfogó kutatások a kabai meteoriton (Comprehensive Research on Kaba Meteorite), Szerk.: Nagy, M., Rózsa, P. \& McIntosh, R. W. Acta Geoscientia Debrecina, Special Issue 1: 55-69. Debrecen University Press. ISSN 1788-44-97 ISBN 978-963-318-053-2

Polgári, M., Gyollai, I., Bérczi, Sz., Veres, M., Gucsik, A., Pál-Molnár, E., 2019: Microbial mediation of textures and minerals - terrestrial or parent body processes? Open Astronomy (de Gruyter), 28(1): 40-60. https://doi.org/10.1515/astro-2019-0004

Steno, N., 1669: De solido intra solidum naturaliter contento dissertationis prodromus. Firenze, 114p. (A szilárd testekben természetes módon előforduló más szilárd testekről). https://doi.org/10.5962/bhl.title.148841

Sztrókay, K.I., Tolnay, V., Földváriné Vogl, M., 1961: A kabai meteorit. Földtani Közlöny, $\mathrm{XCI}(2): 186-207$. https://epa.oszk.hu/01600/01635/00157/pdf/EPA01635 foldtani kozlony_1961_2 186207.pdf

Weidinger., T., Tasnádi, P., 2020: Víz a légkörben. Egyetemi Meteorológiai Füzetek, 32 (Szerk.: Weidinger, T.): 81-104. (Jelen kiadványban.) https://doi.org/10.31852/EMF.32.2020.081.104

Wilhelms, D.E., McCauley, J.F., 1971: Geologic Map of the Near Side of the Moon. U.S. Geological Survey Maps I-703, Washington D. C. https://doi.org/10.3133/i703

Wilhelms, D.E., with sections by John, F. McCauley, Trask, N.J., 1987: The Geologic History of the Moon. US Geological Survey, Professional Paper, 1348. Washington D.C. https://doi.org/10.3133/pp1348 